\title{
Adölesan Annelerin Sosyodemografik Özelliklerinin, Anksiyete ve Depresyon Düzeylerinin Değerlendirilmesi: Ağrı İli Örneklemi
}

\section{Evaluation of Sociodemographic Characteristics, Anxiety and Depression Levels of Adolescent Mothers: Sample of Ağrı Province}

\author{
Halil Kara ${ }^{1}$, Mahmoud Almbaidheen², Ebru Sağlam³ $^{3}$
}

\begin{abstract}
${ }^{1}$ Aksaray Üniversitesi, Tıp Fakültesi, Aksaray Eğitim ve Araştırma Hastanesi, Çocuk ve Ergen Psikiyatrisi Anabilim Dalı, Aksaray, Türkiye

${ }^{2}$ Ağrı Eğitim ve Araştırma Hastanesi, Çocuk ve Ergen Psikiyatrisi Anabilim Dalı, Ağrı, Türkiye

${ }^{3}$ Aksaray Eğitim ve Araştırma Hastanesi, Çocuk ve Ergen Psikiyatrisi Anabilim Dalı, Aksaray, Türkiye
\end{abstract}

Yazışma Adresi: Halil Kara, Aksaray Üniversitesi, Tıp Fakültesi, Aksaray Eğitim ve Araştırma Hastane, Çocuk ve Ergen Psikiyatrisi Anabilim Dalı, Aksaray, Türkiye e-posta: drhalilkara85@gmail.com

Geliş Tarihi/Received: 5 Eylül 2021 Kabul Tarihi/Accepted: 29 Kasım 2021

\begin{abstract}
Öz
Amaç: Evlilik izni için yönlendirilen adölesan annelerin sosyodemografik özelliklerinin, anksiyete ve depresyon düzeylerinin retrospektif olarak değerlendirilmesi amaçlanmıştır.

Hastalar ve Yöntem: 2018-2020 tarihleri arasında evlilik izni için polikliniğe başvurduğu dönemde anne olan 65 ergen olgu dahil edilmiştir. Olguların psikiyatrik değerlendirmelerini içeren hastane kayıtları, sosyodemografik verileri ve düzenlenmiş adli raporları retrospektif olarak incelenmiştir. Değerlendirildiği dönemde depresyon ve anksiyete düzeylerini belirlemek amacıyla Anksiyete ve Depresyon Ölçeği-Yenilenmiş (ÇADÖ-Y) öz bildirim ölçeğini doldurmaları istenmiştir ve bilişsel gelişimin değerlendirilmesi için psikolog tarafından uygulanan Kent E-G-Y ve Porteus Labirentleri zeka testleri uygulanmıştır.

Bulgular: Çalışmaya alınan olguların yaş ortalaması $16,33 \pm 0,307$ yıldı. Gayriresmi evlilik yaptıkları yaşlar

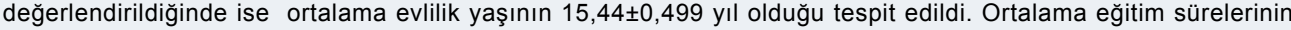
$5,08 \pm 1,461$ yıl olduğu görülmüştür. Gayriresmi evlilik yapmadan önce olguların $\% 70,8$ 'i köyde, $\% 29,2$ kentte yaşıyorken evlilik sonrası ise olguların \%53,8'i köyde, \% 46,2 'sinin kentte yaşıyordu. Yapılan gayriresmi evliliklerin \% 27,7'sinin ise akraba evliliği olduğu tespit edilmiştir. Olguların kliniğe başvurdukları esnada sahip oldukları çocukların yaş ortalaması $4,05 \pm 3,701$ ay olduğu saptanmıştır.

Sonuç: Erken evlilik yapan ve 18 yaş öncesi doğum yapan kızların eğitim sürelerinin ve sosyoekonomik düzeylerinin düşük, eşleri ile aralarındaki yaş farkının fazla, eşlerinin iş imkanlarının kısıtı olduğunu ortaya koymaktadır. Erken yaş evlilikleri önlemeye yönelik müdahale programlarının ve yasal düzenlemelerin geliştirilmesi, hem ergen evliliklerin hem de ergen anne olmanın ortaya çıkardığı olumsuz sonuçların engellenmesine katkıda bulunabilir.
\end{abstract}

Anahtar Kelimeler: Erken evlilik, adölesan anne, anksiyete, depresyon

\section{Abstract}

Aim: It was aimed to retrospectively evaluate the sociodemographic characteristics, anxiety and depression levels of adolescent mothers who were referred for marriage leave.

Patients and Methods: 65 adolescent cases who became mother when they applied to the outpatient clinic for marriage permission between 2018-2020. Hospital records, sociodemographic data and edited forensic reports including psychiatric evaluations of the cases were reviewed retrospectively. In order to determine their depression and anxiety levels during the evaluation period, they were asked to fill in the anxiety and depression scale-revised self-report scale and kent e-g-y and porteus labyrinths intelligence tests applied by the psychologist were applied to evaluate the cognitive development.

Results: The mean age of the subjects included in the study was $16.33 \pm 0.307$ years. It was determined that the mean age at which they were married unofficially was $15.44 \pm 0.499$ years. It was observed that the average education period was $5.08 \pm 1.461$ years. Before the unofficial marriage, $70.8 \%$ of the cases lived in the village and $29.2 \%$ in the city, after the marriage, $53.8 \%$ of the cases lived in the village and $46.2 \%$ in the city. It has been determined that $27.7 \%$ of unofficial marriages are consanguineous marriages. It was determined that the mean age of the children of the patients when they applied to the clinic was $4.05 \pm 3,701$ months.

Conclusion: Girls who married early and gave birth before the age of 18, it reveals that their education period is short, their socioeconomic level is low, the age gap with their spouses is high, and their spouses' job opportunities are limited. The development of intervention programs and legal regulations aimed at preventing early marriages may contribute to the prevention of both adolescent marriages and the negative consequences of being an adolescent mother.

Key words: Early marriage, adolescent mother, anxiety, depression

Atıf yapmak için: Kara H, Almbaidheen M, Sağlam E. Adölesan Annelerin Sosyodemografik Özelliklerinin, Anksiyete ve Depresyon Düzeylerinin Değerlendirilmesi: Ağrı İli Örneklemi. Selcuk Med J 2021;37(4): 351-358

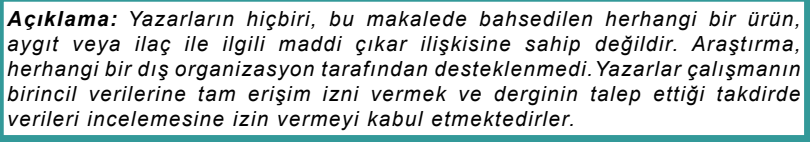

Açıklama: Yazarların hiçbiri, bu makalede bahsedilen herhangi bir ürün, herhangi bir dış organizasyon tarafından desteklenmedi. Yazarlar çalıșmanın verileri incelemesine izin vermeyi kabul etmektedirler. 


\section{GíRiş}

Ergenlik dönemi, kişinin biyolojik, psikolojik ve sosyal değişimler yaşadığı ve çocukluktan erişkinliğe geçiş sürecini içeren bir süreç olarak tanımlanmakta ve Dünya Sağlık Örgütü'ne (DSÖ) göre bu dönem 10-19 yaş aralığını kapsamaktadır (1). Bu dönem, eğitime odaklanılan, yetişkinlik döneminde sahip olunması gereken becerilerin edinilerek geliştirilmesi gereken bir dönemdir. Ancak erken yaşta yapılan evlilikler, ergenlik sürecinde gelişmesi beklenen özellikler sebebiyle çocukların eğitim alma, meslek edinme, sosyoekonomik bağımsızlığını elde etme ve bunu sürdürme, kimlik ve benlik saygısının gelişimini gerçekleştirememe gibi birçok soruna neden olmaktadır. Ayrıca kimlik gelişim sürecinde olan bir kız çocuğuna eş ve anne olma, ev yönetimi gibiyeni sorumluluklar getirmekte, depresyon, uyum bozukluğu, travma sonrası stres bozukluğu, konversiyon bozukluğu ve intihar girişimi gibi çeşitli psikiyatrik bozuklukların da gelişimine neden olmaktadır (2-8).

Erken yaşta annelik deneyimi sonrası doğan çocukların bilişsel, akademik ve davranışsal sorunlara daha yatkın olduğu, çocuk istismar (fiziksel ve cinsel) ve inmaline maruz kalma riskinin arttığı bilinmektedir (9-14). Erken yaşta gerçekleşen evliliklerin daha sık evlilik sorunları, aile içi şiddet ve boşanma gibi toplumsal sorunlara da neden olduğu bildirilmektedir $(15,16)$. Adölesan gebelikler ve adölesan gebelikler sonucunda oluşan adölesan annelik beraberinde getirdiği sorunlarla birlikte günümüzde halen önemini yitirmemiştir. Literatüre baktığımızda, hem geçmişte hem de günümüzde erken yaşta evliliklerin kırsal bölgelerde diğer bölgelere göre daha yaygın olarak gerçekleştiği, dünya genelinde ise Orta Doğu ve Sahra Altı Afrika bölgelerinde daha fazla olduğu bildirilmektedir $(17,18)$. Sosyoekonomik seviyenin düşük olması, erken yaşta evliliğin neden olduğu fiziksel, ruhsal ve toplumsal sorunların gelişim riskini arttırabileceğini düşündürmektedir. Gelişmekte olan ülkelerde her yıl 15-19 yaş arası yaklaşık 12 milyon kız adölesan ve 15 yaş altı en az 777.000 kız adölesan doğum yapmakta, 15-19 yaş arası kız adölesan en az 10 milyon istenmeyen gebelik yaşamaktadır (17).

Çalışmamızda Ağrı ilinde 2018-2020 yılları arasında adli makamlar tarafından evlilik izni için çocuk ve ergen ruh sağlığı ve hastalıkları polikliniğine ruhsal açıdan değerlendirilmeleri için yönlendirilen adölesan annelerin sosyodemografik özelliklerinin, anksiyete ve depresyon düzeylerinin retrospektif olarak değerlendirilmesi amaçlanmıştır. Daha önce Ağrı ilinde erken yaşta evlilik yapmış 8 çift ile yapılan görüşmeye dayanan ve erken evliliği sosyokültürel bağlamda değerlendiren bir makale 2019 yılında yayınlanmıştır (18). Bizim çalışmamız ise aynı bölgedeki erken evlilik sorunlarına daha geniş kapsamlı bir bakış açısı elde edilmesini sağlayacaktır. Aynı zamanda iki çalışmanın karşılaştırılması ile yıllar içinde erken yaşta evlilikle ilgili aynı toplumdaki bakış açısında nasıl bir değişiklik olup olmadığı yönünde de fikir elde edilebilecektir. Çalışmanın Ağrı ilinde yapılmış olmasının bir diğer ilgi çekici sebebi ise Mart 2019 e-okul verilerine göre hem kadınlarda, hem de erkeklerde evlenme ve nişanlanma nedeniyle okula devam etmeyen öğrenci sayısının en yüksek olduğu ilin Ağrı olduğunu göstermektedir (19). Çalışmamızda Ağrı ilinde 2018-2020 yılları arasında adli makamlar tarafından evlilik izni için çocuk ve ergen ruh sağlığı ve hastalıkları polikliniğine ruhsal açıdan değerlendirilmeleri için yönlendirilen adölesan annelerin sosyodemografik özelliklerinin, anksiyete ve depresyon düzeylerinin retrospektif olarak değerlendirilmesi amaçlanmıştır

\section{HASTALAR VE YÖNTEM}

Çalışmaya, 2018-2020 tarihleri arasında Ağrı Eğitim ve Araştırma Hastanesi Çocuk ve Ergen Ruh Sağlığı ve Hastalıkları Polikliniği'ne adli makamlar tarafından "olağanüstü evlenme yaşı (16 yaşın dolduğu ama 17 yaşın dolmadığı yaş aralığı)", "evliliğine ruhen ve bedenen bir engel durumunun olup olmadığına dair değerlendirilmesi” talebiyle adli rapor düzenlenmesi için yönlendirilen ve değerlendirilen, başvurduğu dönemde doğum yapmış 65 ergen olgu dahil edilmiştir. Çalışma öncesi Ağrı Eğitim ve Araştırma Hastanesi Etik Kurulu'ndan ve Ağrı İ Sağlık Müdürlüğü'nden onay ve izin alınmıştır (17.02.2021, No:2021/39). Retrospektif arşiv taramasına dayalı bir çalışma olduğu için hasta onamı alınmamıştır.

Olguların ruhsal değerlendirmelerini içeren hastane sistemindeki notlar, sosyodemografik verileri ve düzenlenmiş adli raporlar retrospektif olarak incelenmiştir. Değerlendirildiği dönemde depresyon ve anksiyete düzeylerini belirlemek amacıyla Anksiyete ve Depresyon Ölçeği-Yenilenmiş (ÇADÖ-Y) öz bildirim ölçeğini doldurmaları istenmiştir. Çocuk Ergen Anksiyete Depresyon Ölçeğinin kesme noktasının üstünde kalan tanılar ile sosyodemografik özellikler arasındaki ilişkiye de bakılmıştır. Bilişsel gelişimin değerlendirilmesi için psikolog tarafından uygulanan Kent E-G-Y ve Porteus Labirentleri zeka testleri uygulanmıştır. Bölgede yaşayan halkın etnik 
bir dil kullanması, ancak zeka testi uygulayıcılarının bu dile yeteri kadar hakim olmayışı ve bazı hastaların okuma yazma bilmemesi sebebiyle en optimal zeka testi olarak kent E-G-Y testi, ihtiyaç duyulan hastalara uygulanmıştır. Klinik muayenemizde zeka ile ilgili bir patoloji düşünülmediyse psikometrik zeka ölçümüne intiyaç duyulmamıştır. Toplamda 47 hastaya zeka testi uygulanmıştır.

\section{Çocuklarda Anksiyete ve Depresyon Ölçeği- Yenilenmiş (ÇADÖ-Y):}

Çocuk ve ergenlerde DSM-IV'e dayalı anksiyete bozuklukları ve depresyonu taramak amacıyla geliştirilmiştir (19). Ebeveyn ve çocuk formu mevcuttur. Yaygın ansiyete bozukluğu, ayrılık anksiyete bozukluğu, sosyal anksiyete bozukluğu, panik bozukluk, obsesif-kompulsif bozukluk ve major depresif bozukluk olmak üzere 6 alt ölçek ve 47 maddeden oluşmaktadır. Her madde 0 ile 3 arası puanlanmaktadır. Türkçe geçerlilik ve güvenilirlik çalışması Görmez ve arkadaşları tarafından yapılımıştır (20). Araştırmamızda çocuk formu kullanılmıştır.

\section{Porteus Labirentleri Testi:}

Bireyin planlama ve yeniliklere uyum becerilerini saptamak için Porteus tarafından geliştirilmiş, performansa dayalı bir zekâ testidir (21). Kâğıt ve kalem kullanılarak uygulanır ve süre sınırlaması ve okur-yazar olma şartı yoktur. Porteus Labirentleri Testi Toğrol tarafından Türkçe'ye uyarlanmıştır (22).

\section{Kent E-G-Y Testi:}

Kent tarafından geliştirilmiş, sözel performansa dayanan bir kâğıt-kalem testidir (23). Konuşma, işitme ve sözel ifade sorunu olmayan hastalara ve sağlıklı bireylere uygulanabilir. Uygulamada süre ve zaman sınırlaması yoktur. 10 sorudan oluşan bu zekâ testinin uygulanması ve değerlendirilmesi oldukça basittir. Yönerge verilirken testteki sorular okunur, yönergeye herhangi bir ekleme yapılmaz. Eğer kişi soruları anlamadıysa ve uygulayıcı tarafından kişinin bu soruyu aslında cevaplayabileceği şeklinde bir kanaate varıldıysa soru hakkında yönlendirme yapmayacak kısa biraçıklama yapılabilir. Her doğru yanıt "1" puan alır ve sonucunda kişinin zekâ yaşı tespit edilir

\section{İstatistiksel analiz}

Verilerin analizi için SPSS 21 istatistik paket programı kullanılmıştır. Tanımlayıcı istatistikler ortalama, standart sapma, minimum, maksimum değerler, sayı ve yüzde olarak belirtilmiştir. Bağımsız grupların karşılaştırılmasında ise ki-kare testi ile kullanılmıştır. Çalışmada istatistiksel anlamlılık düzeyi $p<0,05$ olarak kabul edilmiştir.

\section{BULGULAR}

Çalışmamıza 18 yaş altında, gayriresmi evlilik yapmış ve adölesan anne olan 65 olgu dahil edilmiştir. Olguların başvuru sırasındaki yaş ortalaması 16,33

Tablo 1. Evlilik yapan eşlerin yaş özellikleri ve evlilik süreleri

\begin{tabular}{|c|c|c|c|}
\hline & Ortalama yaş (yıl) & Minimum & Maximum \\
\hline Vakaların başvuru sırasındaki yaş özellikleri & $16,33 \pm 0,30$ & 16 & 17 yıl 3 ay \\
\hline Kızların gayri resmi evlilik yaptıkları yaş & $15,44 \pm 0,49$ & 13 yıl 9 ау & 16 yıl 3 ay \\
\hline Kızların toplamda aldığı eğitim süreleri & $5,08 \pm 1,46$ & 0 & 8 \\
\hline Evlenilen erkeğin kliniğe başvuru esnasındaki yaşı & $24,55 \pm 2,46$ & 19 & 35 \\
\hline \multirow[t]{2}{*}{ Eşlerin yaş farkı } & $8,31 \pm 2,55$ & 2,75 & 18,92 \\
\hline & Ortalama süre (ay) & Minimum & Maximum \\
\hline Gayri resmî evli yaşadıkları süre & $13,95 \pm 4,89$ & 13,95 & 36 \\
\hline
\end{tabular}

Tablo 2. ÇADÖ-Y ölçeği puanlarının, alt ölçeklere göre dağılımı

\begin{tabular}{|c|c|c|c|c|c|c|c|c|}
\hline & $\begin{array}{l}\text { Ayrilık } \\
\text { kaygisı }\end{array}$ & $\begin{array}{l}\text { Yaygın } \\
\text { anksiyete } \\
\text { bozukluğu }\end{array}$ & $\begin{array}{l}\text { Panik } \\
\text { bozukluk }\end{array}$ & $\begin{array}{l}\text { Sosyal } \\
\text { fobi }\end{array}$ & $\begin{array}{l}\text { Obsesif- } \\
\text { kompulsif } \\
\text { bozukluk }\end{array}$ & $\begin{array}{l}\text { Depresif } \\
\text { bozukluk }\end{array}$ & $\begin{array}{l}\text { Toplam } \\
\text { anksiyete } \\
\text { puanları }\end{array}$ & $\begin{array}{l}\text { Toplam } \\
\text { anksiyete } \\
\text {-depresyon } \\
\text { puanları }\end{array}$ \\
\hline Ortalama & 50,63 & 47,02 & 46,82 & 47,26 & 42,37 & 46,71 & 45,82 & 45,71 \\
\hline Standard Sapmalar & 11,379 & 13,536 & 11,034 & 14,044 & 12,223 & 16,038 & 13,172 & 14,072 \\
\hline Minimum & 34 & 29 & 36 & 27 & 29 & 30 & 30 & 29 \\
\hline Maximum & 81 & 81 & 81 & 81 & 78 & 81 & 81 & 81 \\
\hline
\end{tabular}


$\pm 0,30$ yıl (minimum: 16, maksimum 17 yıl 3 ay) olarak saptanmıştır. Gayriresmi evlilik yaptıkları yaşlar değerlendirildiğinde ise ortalama evlilik yaşının 15,44 $\pm 0,49$ yıl (minimum:13 yıl 9 ay, maksimum:16 yıl 3 ay) olduğu tespit edildi. Uygulanan Kent E-G-Y ve Porteus Labirentleri Testleri'nin ortalama puanı 87,98 $\pm 7,80$ olarak saptanmıştır. Eğitim süreleri incelendiğinde; ortalama eğitim sürelerinin $5,08 \pm 1,46$ yıl (minimum: 0, maksimum:8) olduğu görülmüştür. Gayriresmi evlilik yapmadan önce olguların \%70,8'i (n:46) köyde, $\% 29,2$ (n:19) kentte yaşamaktaydı. Gayriresmi evlilik sonrası ise olguların \%53,8'i (n:35) köyde, $\%$ 46,2'sinin (n:30) kentte yaşadığı saptanmıştır.
Evlendikten sonra ise \%27,7'sinin (n:18) çekirdek aile, $\% 72,3$ 'ünün (n:47) ise geniş aile olduğu belirlendi. Olguların annelerinin hiçbirinin çalışmadığı, babaların meslekleri incelendiğinde ise \%27,7'sinin inşaat işçisi, \%26,2'sinin çiftçi, \%10,8' inin işsiz olduğu tespit edilmiştir. Kardeş sayıları incelendiğinde ise ortalama kardeş sayısının 7,23 $\pm 2,344$ (minimum: 2 maksimum: 14) olduğu görülmüştür (Tablo 1 ).

Olguların kliniğe başvurdukları esnada gayriresmi evli yaşadıkları süre ortalama: 13,95 $\pm 4,89$ ay (minimum:13,95, maksimum:36) olduğu saptanmış olup, eşlerinin demografik özellikleri değerlendirildiğinde ise ortalama yaşlarının

Tablo 3. ÇADÖ-Y özbildirim ölçeğinin kesme puanlarına göre belirtilen sorunlar ile sosyodemografik (sdf) özelliklerarasında ilişkinin Ki-kare analizi ile belirlenmesi

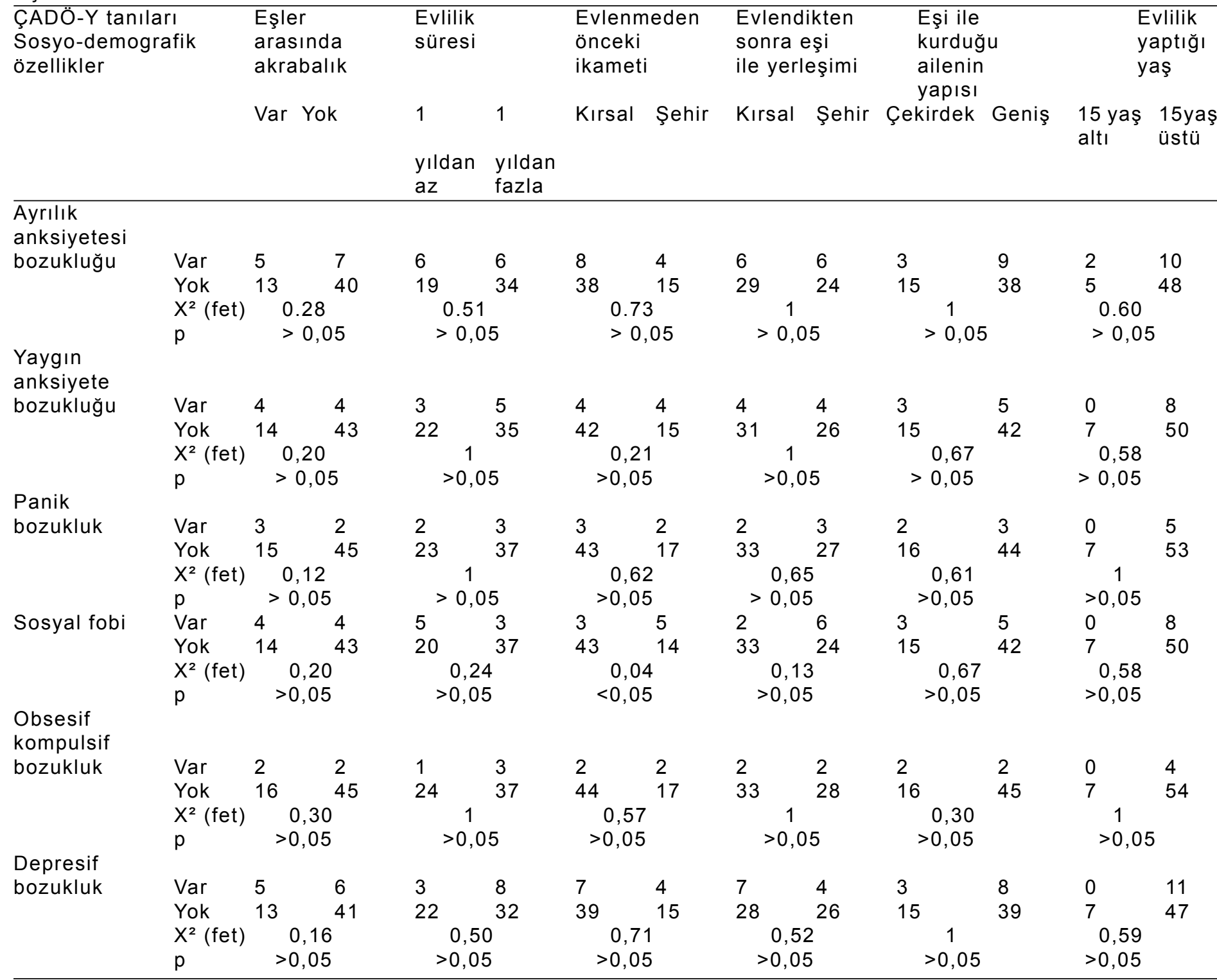

$\mathrm{X}^{2}$ : ki-kare, Fet: fischerınkesinliktesti (fisher's exact test), p anlamlılıkdeğeri 0,05 den küçükolarakalınmıştır (2-tailed). 
24,55 $\pm 2,46$ yıl (mimimum: 19, maksimum: 35) olduğu bulunmuştur. Olguların eşleri ile arasındaki ortalama yaş farkı $8,31 \pm 2,55$ yıl (min: 2,75 , max: 18,92) olarak saptanmıştır. Olguların eşlerinin \% 63'ünün inşaat işçisi olduğu belirlenmiştir. Yapılan gayriresmi evliliklerin \% 27,7'sinin ise akraba evliliği olduğu tespit edilmiştir. Olguların kliniğe başvurdukları esnada sahip oldukları çocukların yaş ortalaması $4,05 \pm 3,70$ ay olduğu saptanmıştır.

Olgulara uygulanan ÇADÖ-Y öz bildirim ölçeği kesme puanlarına göre eşik üzerinde kalan alt ölçek puanları değerlendirildiğinde ise; \%18,5'inde (n:12) ayrılık anksiyete bozukluğu, \%12,3'ünde (n:8) yaygın anksiyete bozukluğu, \% 7,7 'sinde (n:5) panik bozukluk, $\% 12,3$ 'ünde (n:8) sosyal fobi, \%6,2'sinde (n:4) obsesif kompulsif bozukluk, \%16,9'unda (n:4) ise depresif bozukluk alt ölçek puanlarının eşik üzerinde olduğu tespit edilmiştir. Alt ölçek, toplam anksiyete puanları ve toplam anksiyete-depresyon puanlarının dağılımı Tablo 2'de gösterilmiştir (Tablo 2).

Yapılan ki-kare analizi değerlendirildiğinde, evlenmeden önce şehirde yaşayanlarla kırsal kesimde yaşayanlar arasında ÇADÖ-Y sosyal fobi alt ölçeğinin kesme puanına göre, sosyal fobik özellikler olup olmama açısından anlamlı fark vardır $(p<0,05)$
Tablo 3 de tüm ki-kare analizleri detaylı olarak gösterilmiştir. Tablo 3'te tüm ki-kare analizleri detaylı olarak gösterilmiştir (Tablo 3).

Kızların eğitim aldıkları süre, gayri-resmi olarak evli kaldıkları süre, kızların evlendikleri sırada olan kardeş sayıları, kızların gayriresmi olarak evlendiği yaş, evlenilen erkeğin yaşı, evlilik yapan kadin ve erkek arasındaki yaş farkı ile ÇADÖ-Y öz bildirim ölçeği alt testleri arasındaki korelasyona bakılmış, ancak herhangi pozitif veya negatif yönlü bir ilişki bulunulamamıştır. Korelasyon analizi ile ilgili sonuçlar Tablo 4 'te detaylı olarak belirtilmiştir (Tablo 4).

\section{TARTIŞMA}

Bu çalışmada, Ağrı ilinde 2018-2020 yılları arasında evlilik izni için yönlendirilen adölesan annelerin sosyodemografik özellikleri, anksiyete ve depresyon düzeyleri ve bunların ilişkisi retrospektif olarak değerlendirilmiştir. Erken evlilik, birçok ükede olduğu gibi ülkemizde de önemli bir halk sağlığı sorunu olup, çocuğun eğitime devam edememesi, ergen gebeliklerin olması, gebelikle ilgili komplikasyonlar, erken doğum, düşük doğum ağırlıklı bebeklerin doğumu, fetal ölüm gibi çok sayıda bireysel ve toplumsal olumsuz sonuçlara da neden olmaktadır

Tablo 4. ÇADÖ-Y özbildirim ölçeği alt test skorları ile bazı sosyodemografik özellikler arasındaki korelasyonun incelenmesi

\begin{tabular}{|c|c|c|c|c|c|c|c|}
\hline & & $\begin{array}{c}\text { Ayrılık } \\
\text { kaygısı } \\
\text { bozukluğu }\end{array}$ & $\begin{array}{c}\text { Yaygın } \\
\text { anksiyete } \\
\text { bozukluğu }\end{array}$ & $\begin{array}{c}\text { Panik } \\
\text { bozukluk }\end{array}$ & $\begin{array}{l}\text { Sosyal } \\
\text { fobi }\end{array}$ & $\begin{array}{l}\text { Obsesif } \\
\text { kompulif } \\
\text { bozukluk }\end{array}$ & $\begin{array}{l}\text { Depresif } \\
\text { bozukluk }\end{array}$ \\
\hline \multicolumn{8}{|l|}{ Kızların eğitim } \\
\hline \multirow[t]{3}{*}{ aldıkları süre } & $r$ & $-0,18$ & $-0,04$ & $-0,03$ & $-0,07$ & $-0,04$ & 0,00 \\
\hline & $\mathrm{p}$ & 0,14 & 0,74 & 0,78 & 0,57 & 0,70 & 0,96 \\
\hline & $\mathrm{N}$ & 65 & 65 & 65 & 65 & 65 & 65 \\
\hline \multicolumn{8}{|l|}{ Gayri-resmi olarak } \\
\hline \multirow[t]{3}{*}{ evli kaldıkları süre } & $r$ & 0,07 & $-0,01$ & $-0,10$ & 0,07 & $-0,04$ & $-0,04$ \\
\hline & $\mathrm{p}$ & 0,53 & 0,90 & 0,42 & 0,55 & 0,69 & 0,73 \\
\hline & $\mathrm{N}$ & 65 & 65 & 65 & 65 & 65 & 65 \\
\hline \multicolumn{8}{|l|}{ Kızların evlendikleri } \\
\hline \multirow[t]{3}{*}{ sırada olan kardeş sayıları } & $r$ & $-0,15$ & $-0,11$ & $-0,05$ & $-0,17$ & 0,01 & $-0,09$ \\
\hline & $\mathrm{p}$ & 0,23 & 0,34 & 0,69 & 0,17 & 0,89 & 0,44 \\
\hline & $\mathrm{N}$ & 65 & 65 & 65 & 65 & 65 & 65 \\
\hline \multicolumn{8}{|l|}{ Kızların gayri-resmi } \\
\hline \multirow[t]{3}{*}{ olarak evlendiği yaş } & $r$ & 0,03 & 0,20 & 0,10 & 0,14 & 0,13 & 0,20 \\
\hline & $p$ & 0,78 & 0,10 & 0,41 & 0,26 & 0,29 & 0,09 \\
\hline & $\mathrm{N}$ & 65 & 65 & 65 & 65 & 65 & 65 \\
\hline \multirow[t]{3}{*}{ Evlenilen erkeğin yaşı } & $r$ & $-0,12$ & $-0,22$ & $-0,15$ & $-0,14$ & $-0,17$ & $-0,13$ \\
\hline & $\mathrm{p}$ & 0,30 & 0,07 & 0,20 & 0,24 & 0,17 & 0,26 \\
\hline & $\mathrm{N}$ & 65 & 65 & 65 & 65 & 65 & 65 \\
\hline \multirow{4}{*}{$\begin{array}{l}\text { Evlilik yapan kadin ve } \\
\text { erkek arasındaki yaş farkı }\end{array}$} & & & & & & & \\
\hline & $r$ & $-0,08$ & $-0,23$ & $-0,12$ & $-0,16$ & $-0,15$ & $-0,16$ \\
\hline & $\mathrm{p}$ & 0,50 & 0,05 & 0,32 & 0,19 & 0,21 & 0,20 \\
\hline & $\mathrm{N}$ & 65 & 65 & 65 & 65 & 65 & 65 \\
\hline
\end{tabular}

r: Pearson korelasyon katsayısı p: anlamlılık değeri (2-tailed), N: vakasayısı 
(24). Çalışmamızda yer alan olguların tamamının lisede eğitim alması gereken yaş aralığında olmasına rağmen, hiçbirinin okula devam etmediği, ortalama eğitim sürelerinin $5,08 \pm 1,461$ yıl olduğu belirlendi. Ülkemizde yapılan bir başka çalışmada da evlilik izni için başvuran kız ergenlerin \%92'sinin okula devam etmediği saptanmıştır (25). Kız çocuk ve ergenlerin eğitime devam edememelerinin gelecekte meslek edinme ile güçlüklere, düşük sosyoekonomik statüye, aile ve toplumsal yaşamda cinsiyet eşitsizliğine neden olması beklenmekte ve bu bulgular doğrultusunda kız çocuk ve ergenlerin okula devam etmelerinin sağlanması ve buna yönelik politikaların geliştirilmesi, erken evliliklerin ve buna bağlı oluşan sorunların azalmasına katkı sağlayabileceğini düşündürmektedir. Ayrıca kız ergenlerde kısa eğitim sürelerinin sadece erken evliğin sonucu olmayabileceği, aynı zamanda nedeni de olabileceği göz önünde bulundurulmalı ve bu açıdan risk altında olan kız çocukları belirlenmelidir.

Erken evlilikler için en önemli risk faktörlerinden birisinin düşük sosyoekonomik düzey olduğu çeşitli araştırmalarla gösterilmiştir. UNICEF, yoksulluğun çocuk evliliklerin gerçekleşme riskini 2,5 kat arttırdığını bildirmiştir (26). Yapılan çalışmalar erken evliliğe iliş̧in risk faktörleri arasında düşük sosyoekonomik düzeyin ve kısa eğitim süresinin yer aldığını göstermektedir (17, 27-29). Çalışmamızda yer alan olguların \% 70,8'nin gayriresmi evlilik öncesi kırsal bölgede yaşadığı, gayriresmi evlilik sonrasında ise $\% 53,8$ 'inin ise kırsal bölgede yaşamaya devam ettiği, annelerinin hiçbirinin çalışmadığı, babalarının \% 10,8'inin işsiz, \%27,7 sinin ise inşaat işçisi, \%26,2'sinin çiftçi olduğu, ortalama kardeş sayısının 7,23 olduğu tespit edilmiştir. Hane halkının kalabalık olması ve sabit gelirlerinin olmaması, kız çocukları için yapılacak eğitim dahil tüm harcamalara engel oluşturabilir ve evlilik ile evden ayrılmasına yol açabilir. Tüm bu bulgular düşük sosyoekonomik düzeyin hem kısa eğitim süresi hem de erken evlilik için önemli bir risk faktörü olmasını destekler niteliktedir.

Ergenlik dönemi, fiziksel gelişimle birlikte duygusal ve zihinsel gelişimin de devam ettiği, yetişkin rolü için gerekli becerileri henüz edinemediği bir dönemdir (30). Bu dönemde gelişimsel görevlerin ana hatlarının, yakın ilişkilerin kurulması ve geliştirilmesinin, kimlik gelişiminin, gelecek ile ilgili tasarımların şekillenmesinin, bağımsızlık, özgüven ve sosyal becerilerin kazanımının oluştuğunu görürüz. Nöroplastisite kavramından ergen beynine baktığımızda ise davranışların kontrolü, plan yapma, karar verme gibi yüksek bilişsel işlevleri düzenleyen prefrontal korteksin, duyu ve motor görevlerle ilişkili beyin bölgelerine göre daha geç olgunlaştığını bilmekteyiz.

Bu dönemde gerçekleşen erken evlilik, eş ve anne olma gibi yeni rolleri de beraberinde getirmekte, edinilmesi gereken becerileri, meslek sahibi olmayı ve özerkliğin gelişimini engellemektedir. Erken evliliklerde erişkin dönemde yapılan evliliklere göre yüksek eşler arası yaş farkının daha sık görüldüğü, ülkemizdeki evliliklerin yapısını inceleyen bir çalışmada ise eşler arası yaş farkının ortalama 4 olduğu bildirilmektedir $(31,32)$. Çalışmamızda erken evlilik yapan kızların eşleri ile arasındaki yaş farkı ortalama olarak 8,31 $\pm 2,551$ yıl olarak tespit edilmiştir. Bu farkın ülkemizdeki eşler arası ortalama yaş farkına göre oldukça yüksek olması erken evlilik ile ilişkili olabilir.

Ülkemizde evliliklere ilişkin yapılan bir çalışmada akrabaevliliklerininoranı\%21,3, çalışmamızınyapıldığı Ağrı ilininin yer aldığı Kuzeydoğu Anadolu Bölgesi'nde ise $\% 22,8$ saptanmıştır (33). Çalışmamızda ise bu oranın \% 27,7 olduğu bulunmuştur. Hem ülke hem de bölge oranına göre daha yüksek olması, erken evliliğin olası komplikasyonları ile birlikte akraba evliliğinin neden olabileceği olumsuz sonuçların Ağrı ilinde daha fazla olabileceğini ve ek tedbir/ müdahalelerin gerekebileceğini düşündürmektedir. Bunlara ek olarak olguların yalnızca \%27,7'sinin evlendikten sonra çekirdek ailede yaşadığı, eşlerinin \%63'ünün inşaat işçisi olduğu saptanmıştır. Olguların büyük bir bölümünün geniş ailede yaşaması, eşlerinin sabit bir gelirinin olmaması ekonomik bağımsızlığın, özerkliğin sağlanamamasına ve dolayısıyla düşük sosyoekonomik düzeyin devam etmesinde etkili faktörler olabilir.

Erken yaşta evliliklerin psikopatoloji gelişimi üzerine etkileri dünya genelinde ve ülkemizde araştırıldığında, 18 yaş öncesi evlenen ergenlerde psikiyatrik bozukluklukların prevalansında artışa neden olduğu görülmüştür $(28,29,34,35)$. Çalışmamızda ise ÇADÖ-Y ile anksiyete bozuklukları ve depresyona yönelik bir tarama yapılmıştır. Bu ölçek ile tanı konulmamakla birlikte tarama sonuçları literatür ile uyumlu olarak erken evlilik yapan ve doğum yapan kızlarda genel popülasyona göre daha fazla psikopatoloji gelişebileceği konusunda fikir vermektedir.

Çalışmamızda olguların sosyodemografik verileri ile ÇADÖ-Y öz bildirim ölçeği kesme puanlarına göre eşik üzerinde kalan alt ölçek puanları arasında ilişki olup olmadığı değerlendirildiğinde, istatistiksel açıdan 
anlamlı bir ilişki olmadığını söyleyebiliriz. Yalnızca evlenmeden önce şehirde yaşayanlarla kırsal kesimde yaşayanlar arasında, ÇADÖ-Y sosyal fobi alt ölçeğinin kesme puanına göre, sosyal fobik özellikler şehirde yaşayanlarda daha fazla bulunmuştur. Bu veri bize, sosyokültürel olarak daha zorlu yaşam koşullarına sahip çocukların bu zorlukları ile baş edebilmek için daha çok sosyalleşmek zorunda kalması gerekeceği için, sosyal öğrenme prensibine göre, daha dışa dönük olabileceğini düşündürebilir. Ancak tüm karşılaştırmalar göz önüne alınarak, genel olarak değerlendirildiğinde bu sonucun klinik açıdan anlamlı olmadığını söyleyebiliriz. Bu durum çalışmaya dahil edilen olgu sayısının düşük olması, araştırmanın retrospektif olması, sadece bir ilin verilerinin değerlendirilmesi ile ilişkili olabilir. Çalışmanın bölge ve ülke çapında yapılması ile daha objektif bilgiler elde edilebileceği düşünülebilir. Ancak bölgesel yapılan çalışmaların bir avantajı, o bölgede bulunan mikrokültürel özelliklere göre politikalar geliştirilmesini kolaylaştırmasıdır. Bu sebeple öncelikle küçük bölgelerde benzer şekilde yapılan pilot çalışmalara intiyaç duyulmaktadır.

Sonuç olarak çalışmamız erken evlilik yapan ve 18 yaş öncesi doğum yapan kızların eğitim sürelerinin ve sosyoekonomik düzeylerinin düşük, eşleri ile aralarındaki yaş farkının fazla, eşlerinin iş imkanlarının kısıtlı olduğunu ortaya koymaktadır. Erken yaş evlilikleri önlemeye yönelik müdahale programlarının ve yasal düzenlemelerin geliştirilmesi, hem ergen evliliklerin hem de ergen anne olmanın ortaya çıkardığı olumsuz sonuçların engellenmesine katkıda bulunabilir.

Çıkar Çatışması: Çalışmada herhangi bir çıkar çatışması yoktur.

Finansal Çıkar Çatışması: Çalışmada herhangi bir finansal çıkar çatışması yoktur.

Yazışma Adresi: Halil Kara, Aksaray Üniversitesi, Tıp Fakültesi, Aksaray Eğitim ve Araştırma Hastanesi, Çocuk ve Ergen Psikiyatrisi Anabilim Dalı, Aksaray, Türkiye

E-mail: drhalilkara85@gmail.com

\section{KAYNAKLAR}

1. Kütük S. Adölesan gebelik riskleri ve sorunları. Turk J Family Practice 2012;S31-4.

2. Yakubu I, Salisu WJ. Determinants of adolescent pregnancy in sub-Saharan Africa: A systematic review. Reprod Health 2018;15(1):1-11

3. Gage AJ. Association of child marriage with suicidal thoughts and attempts among adolescent girls in Ethiopia. J Adolescenc Health 2013;52(5):654-6.

4. Olajubu AO, Omoloye GO, Olajubu TO, et al. Stress and resilience among pregnant teenagers in Ile-Ife, Nigeria. Eur J of Midwifery 2021;5.

5. Corley A, Glass N, Remy MM, et al. A latent class analysis of gender attitudes and their associations with intimate partner violence and mental health in the Democratic Republic of Congo. Int J Environ Res Public Health 2021;18(8):4063.

6. Kawakita T, Wilson K, Grantz KL, et al. Adverse maternal and neonatal outcomes in adolescent pregnancy. J Pediatr Adolesc Gynecol 2016;29(2):130-6.

7. Islam MM, Khan N, Rahman M. Factors affecting child marriage and contraceptive use among Rohingya girls in refugee camps. Lancet Reg Health West Pac 2021;12:100175.

8. John NA, Edmeades J, Murithi L. Child marriage and psychological well-being in Niger and Ethiopia. BMC Public Health 2019;19(1):1-12.

9. O'Callaghan M Development of Adolescent Mothers Ed: Whitman TL, Borkowski JG, Keogh DA, Weed K In: Interwoven lives: Adolescent mothers and their children. Philadelphia, PA: Psychology Press 2001. p:65-95.

10. Moore KA, Morrison DR, Greene AD. Effects on the children born to adolescent mothers. In: Maynard RA, ed. Kids having kids. London: Routledge 2018;145-80.

11. Nagin DS, Farrington DP, Pogarsky G. Adolescent mothers and the criminal behavior of their children. Law\&Soc'y Rev 1997;31:137.

12. Brooks-Gunn J, Furstenberg JR FF. The children of adolescent mothers: Physical, academic, and psychological outcomes. Developmental Review 1986;6(3):224-51.

13. Dukewich TL, Borkowski JG, Whitman TL. Adolescent mothers and child abuse potential: An evaluation of risk factors. Child Abuse Negl 1996;20(11):1031-47.

14. Buchholz ES, Korn Bursztyn C. Children of adolescent mothers: Are they at risk for abuse? Adolescence 1993;28(110):361.

15. Nasrullah M, Zakar R, Zakar MZ. Child marriage and its associations with controlling behaviors and spousal violence against adolescent and young women in Pakistan. Adolesc Health 2014;55(6):804-9.

16. Raj A, Saggurti N, Lawrence $D$, et al. Association between adolescent marriage and marital violence among young adult women in India. Int J Gynaecol Obstet 2010;110(1):35-9.

17. Ergöçmen $A B$, Keskin $F$, Yüksel Kaptanoğlu I. Türkiye'de çocuk yaşta, erken ve zorla evlilikler: 1993-2018 Türkiye Nüfus ve Sağlık Araştırmaları Veri Analizi. UNFPA Türkiye. Aralık 2020. S.78.

18. World Health Organization: Adolescent pregnancy Factsheet [Internet]. World Health Organization 2020. [cited January 2020]. Available from: https://www.who.int/news-room/ factsheets/detail/adolescent-pregnancy

19. Chorpita BF, Yim L, Moffitt C, et al. Assessment of symptoms of DSM-IV anxiety and depression in children: A revised child anxiety and depression scale. Behav Res Ther 2000;38(8):835-55.

20. Gormez V, Kılınçaslan A, Orengul AC, et al. Psychometric properties of the Turkish version of the Revised child anxiety and depression scale-child version in a clinical sample. Psychiatry Clin Psychopharmacol 2017;27(1):84-92.

21. Porteus SD. The porteus maze test and intelligence. Pacific Books 1950.

22. Toğrol B. RB cattell zeka testinin $2 a$ ve $2 b$ formlari ile porteus labirenti zeka testinin 1300 Türk çocuğuna uygulanmasi. Psikoloji Çalışmalari 1974;11:1-32. 
23. Kent GH. Emergency battery of one-minute tests. J Psychol 1942;13:141-64.

24. Sezgin AU, Punamäki RL. Impacts of early marriage and adolescent pregnancy on mental andsomatic health: The role of partner violence. Arch Womens Ment Health 2020;23(2):155.

25. Nasiroglu S, Semerci B. Mental assessment of girls consulting for early marriage and identifying risk factors. Anatolian $\mathrm{J}$ Psych 2017;18(5):460-7.

26. UNICEF. Ending Child marriage: Progress and prospects July 2014. https://data.unicef.org/resources/ending-childmarriage-progress-and-prospects/ Accessed on, 26. September 2021.

27. Raj A. When the mother is a child: The impact of child marriage on the health and human rights of girls. Archives of Disease in Childhood 2010;95(11):931-5.

28. Soylu N, Ayaz M. Adli değerlendirme için yönlendirilen küçük yaşta evlendirilmiş kız çocuklarının sosyodemografik özellikleri ve ruhsal değerlendirmesi, Anadolu Psikiyatri Derg 2013;14:136-44.
29. Eyüboğlu D, Eyüboğlu M. Küçük yaşta evlendirilmek istenen çocuklarda psikiyatrik bozukluklar ve sosyodemografik özellikler. J Clin Psy 2018;21:122-9.

30. Akyel $B$, Kayiş $H$, Yüncü $Z$. Ergenlikte beyin gelişimi, risk alma ve bağımlılığa yatkınlık. Türkiye Klinikleri 2018;134-9.

31. Erulkar A. Early marriage, marital relations and intimate partner violence in Ethiopia. Int Perspect Sex Reprod Health 2013;39:6-13.

32. Hacettepe Üniversitesi Nüfus Etütleri Enstitüsü. 2013 Türkiye Nüfus ve Sağlık Araştırması-TNSA. Hacettepe Üniversitesi Nüfus Etütleri Enstitüsü, T.C. Kalkınma Bakanlığı ve TÜBiTAK, Ankara;2014.

33. Turğut M, Feyzioğlu S. Türkiye aile yapısı araştırması: Tespitler, öneriler. T.C. Aile ve Sosyal Politikalar Bakanlığı Aile ve Toplum Hizmetleri Genel Müdürlüğü, İstanbul;2014.

34. Le Strat $Y$, Dubertret $C$, Le Foll B. Child marriage in the United States and its association with mental health in women. Pediatrics 2011;128:524-30.

35. Kasım B, Cem U, Mustafa K, et al. Evaluation of the early age married girls applying to our department. Open J Pediatr 2015;5:334-8. 